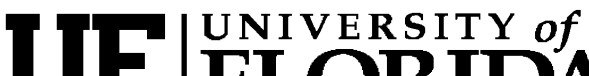 FLORIDA \\ IFAS Extension
}

\section{Florida Crop/Pest Management Profile: Avocado ${ }^{1}$}

\author{
Mark A. Mossler and Jonathan H. Crane ${ }^{2}$ \\ Production Facts
}

As of 2002, the Florida avocado industry consisted of about 6,600 bearing acres, 737 growers, and 35 registered handlers/shippers. Most avocados produced in Florida ( 80 percent) are sold outside the state. To lawfully sell more than 55 pounds of avocados per day in Florida, permits must be obtained from the Florida Department of Agriculture and Consumer Services (FDACS). Because of this requirement, most avocadoes grown in Florida are sold to packinghouses directly from the farm (1).

- In 2004-2005, Florida produced an estimated 28,000 tons of avocados. The value of the 2004-2005 avocado crop was approximately $\$ 14.5$ million or $\$ 0.26$ per pound (1).

- In 2004-2005, Florida was second in the United States in avocado production, behind California. Florida avocadoes accounted for 9 percent of total national avocado production that year. However, Florida avocados accounted for only 5 percent of the national value of avocado production that year. This discrepancy is because Florida avocados sell for less than the price (on a weight basis) garnered by California avocados (1).

- Three races of avocado are most commonly planted: West Indian, Guatemalan, and Mexican. These avocado races differ in blooming/maturity season, development period, fruit size, skin texture/color, oil content, and cold hardiness. In Florida, West Indian and West Indian-Guatemalan hybrid cultivars predominate (2).

- Avocado may be self- or cross-pollinating, and varieties are categorized as $\mathrm{A}$ and $\mathrm{B}$, based on reproductive functionality (2).

\section{Production Regions}

Within Florida, avocado (Persea americana) is grown exclusively in South Florida, and more than 99 percent of Florida-grown avocado is produced in Miami-Dade County. Of the 737 farms in Florida reported in 2002 to be growing avocado, 88 percent of those farms were less than 15 acres in size. These small farms account for about a third of total avocado production in Florida. While only 5 percent of

1. This document is CIR 1271, one of a series of the Pesticide Information Office, Agronomy Department, Florida Cooperative Extension Service, Institute of Food and Agricultural Sciences, University of Florida. For additional information, contact the Pesticide Information Office, University of Florida, P. O. Box 110710, Gainesville, Fl 32611-0710, (352) 392-4721. Original date of publicatn, September 2001. Revised September 2008. Please visit the EDIS Web site at http://edis.ifas.ufl.edu.

2. Mark A. Mossler, doctor of plant medicine, Agronomy Department, Pesticide Information Office, Gainesville, FL, and Jonathan Crane, professor, Horticultural Sciences Department, Tropical Research and Education Center, Homestead, FL, Cooperative Extension Service, Institute of Food and Agricultural Sciences, University of Florida, Gainesville, FL.

The Institute of Food and Agricultural Sciences (IFAS) is an Equal Opportunity Institution authorized to provide research, educational information and other services only to individuals and institutions that function with non-discrimination with respect to race, creed, color, religion, age, disability, sex, sexual orientation, marital status, national origin, political opinions or affiliations. U.S. Department of Agriculture, Cooperative Extension Service, University of Florida, IFAS, Florida A. \& M. University Cooperative Extension Program, and Boards of County Commissioners Cooperating. Larry Arrington, Dean 
Florida farms that reported in 2002 to be producing avocado are 50 acres or above, approximately half of the avocado production in Florida is from farms of that size. Another 20 percent of Floridas avocado production is from the 7 percent of the growers whose acreage is between 25 and 49.9 acres (1).

\section{Production Practices}

The avocado tree is classified as an evergreen and is in the laurel family. Avocado is indigenous to tropical America and was first imported into Florida in 1833. The tree can grow to a height of 60 feet, but it is generally maintained at a height of 20 feet for ease of harvest and maintenance. The fruit vary in shape, and weight ranges from a few ounces to five pounds. Oil content of Florida-grown avocado generally ranges from 3 - 15 percent, and the fruit does not ripen until it is picked or falls off the tree. This phenomenon allows avocado growers to "store" the fruit on the trees until labor or markets are available/favorable. The Florida Avocado Administrative Committee establishes dates each season at which time certain size fruit are considered to be mature $(2,3)$. Growers harvest based on the dates set annually by this committee.

Avocado should be planted in well drained soil, such as the well drained rockland and sandy soils present in South Florida. Avocado does not tolerate flooding or standing water, as it is predisposed to Phytophthora infection. Consistently wet soils also lead to reduced yield and nutritional deficiencies. The soils present in South Florida generally fulfill the requirements for avocado once the fertility of the soil has been amended.

Although avocado does not tolerate consistently wet soils, avocado trees have a high water requirement. During dry periods, irrigation systems for avocado should provide 1 inch of water per week (2).

Avocado cultivars commonly used in Florida are 'Simmonds', 'Choquette', 'Monroe', 'Lula', 'Nadir', and 'Booth' varieties. 'Simmonds' and 'Nadir' are early-maturing varieties (late June). 'Booth', 'Waldin', and 'Choquette' ripen in October. 'Lula', 'Taylor' and 'Monroe' mature in November. The largest avocado production in Florida occurs from August through December (2).

Avocado is generally propagated vegetatively. Cleft and veneer grafting techniques are used during the cooler months to merge healthy seedling rootstock (typically Lula or Waldin) with scions from the desired variety. Scions may also be added to mature trees in a technique referred to as top-working. Top-worked trees produce marketable fruit within two or three years while new plantings require three to four years $(2,3)$.

Avocado trees are planted 15 - 25 feet apart within rows with 25 - 30 feet between rows. Consequently, a grove $8-12$ years old would have about 75 trees per acre. The trees reach full-bearing potential by the seventh year. The useful life of an avocado tree is approximately 40 years although 75-year-old trees have been reported. During the life of a grove, healthy trees are pruned, and diseased and undesirable trees are removed and replaced with "resets" -- mature trees that have been moved and replanted $(2,3)$.

Fewer than one percent of the self- or cross-pollinating flowers on an avocado tree set fruit. Varieties such as 'Waldin', 'Lula', and 'Taylor' -- A varieties -- fruit well in solid plantings while B varieties, such as 'Booth', do not. To facilitate adequate pollination, $B$ varieties should be interspersed with A varieties. Some varieties bear many fruit, a portion of which abscise. Other varieties bear fewer fruit, but these are retained until maturity. Often a tree will bear well only every other year.

\section{Worker Activities}

Avocado trees are generally picked twice a season. Larger fruit are picked first, leaving the smaller fruit to enlarge. Harvesting is quite labor intensive, and laborers often wear cotton gloves and use canvas picking bags to minimize damage of the soft fruit. The picker must be able to selectively choose only desirable avocados and pick them without injuring the fruit. A worker can generally pick up to three acres daily. Workers may also spend several weeks a year pruning avocado tree limbs. 
The fruit are packed into various size boxes in the packinghouse. Some fruit is marketed under the grower's name. However, a portion of the avocado grown each season in Florida is pooled and sold by the smaller growers. Off-farm activity -supplemental employment -- is high among Florida avocado growers. This same grower group also cultivates other tropical crops in Florida. For this group, avocado only comprise 18 percent of total sales (3).

\section{Insect/Mite Management}

\section{Insect/Mite Pests}

In Florida, principal pests on avocado are as follows:

- Mites -- avocado red mite, avocado brown mite, and avocado bud mite;

- Avocado lace bug;

- Mirids;

- Scale -- dictyospermum scale, Florida red scale, Florida wax scale, lantania scale and pyriform scale;

- Avocado tree girdler;

- Redbanded thrips; and

- Fire ants.

Minor and occasional pests include ambrosia beetles, aphids, mealybugs, avocado leafroller, avocado looper, banded cucumber beetle, caterpillars, grasshoppers, and slugs/snails (4).

Mites (Oligonychus yothersi, Oligonychus punicae, Tegolophus perseaflorae)

Spider mites of the genus Oligonychus commonly infest avocados in Florida. Feeding is first confined to the upper leaf surface along the midrib and then spreads along secondary veins. The areas along the veins become reddish-brown. Damage by the spider mites is commonly observed from October through February, causing a reduction in photosynthesis of up to 30 percent. Infested leaves often abscise prematurely. Control measures are often started when mite pressures reach six or more mites per leaf. For spider mites in general, life cycles may range from 5 to 20 days. Lifespan of the spider mite may be as long as one month. The female lays several hundred eggs over a lifetime. The eggs are capable of overwintering within the grove (4).

Avocado bud mite (T. perseaflorae) populations start to increase from March to May. These mites are found on buds and on developing fruit. The feeding of the avocado bud mite causes necrotic spots and irregular openings in apical leaves and may cause fruit deformation and discoloration (4).

\section{Avocado Lace Bug (Pseudacysta perseae)}

The avocado lace bug was historically regarded as having a limited distribution throughout the Florida peninsula, causing little economic damage. However, the number of complaints about leaf damage resulting from this insect has increased recently.

These small $(2 \mathrm{~mm})$ insects are black with pale-yellow legs and antennae. The shape is classically "bug-like" (i.e., belonging to the family Hemiptera). This species is the only one described for the genus Pseudacysta, so identification to genus is imperative to get to the specific level. (For more on identification of the avocado lace bug, see EDIS Publication IN166, http://edis.ifas.ufl.edu/IN166.) The avocado serves as host to the bug, as do red bay and camphor in other parts of the Deep South (5).

The avocado lace bug inhabits the undersurface of leaves and feeds by penetrating the tissue with its piercing-sucking mouthparts and removing plant sap. The bug lives in colonies, depositing eggs upright in irregular clusters in the same area that the bug inhabits. The life cycle of the avocado lace bug is about three weeks.

When a colony is present, dark, sticky secretions cover the leaf surface. The avocado lace bug is often found during dry months (November through February). It is believed that the feeding wounds produced by the bug serve as entry points for anthracnose fungi, which produce large, necrotic blotches on avocado leaves. Field surveys have shown that certain avocado varieties ('Loretta' and 
'Booth 8') suffered as much as 28 percent damage to the leaves due to damage from these feeding wounds and the resulting fungal infections. Additionally, Simmonds avocado trees suffered complete loss of fruit set and premature defoliation when 100 percent of the leaves were infested. The most important predators of the lace bug are two egg parasitoids, the green lacewing and a predacious mirid $(5,6)$.

Mirids (Daghbertus fasciatus, Daghbertus olivaceous, Rhinacloa sp.)

These sucking insects are small $(3 \mathrm{~mm})$ and vary in color from green to brown. They are prevalent during the avocado-flowering months, January through April. The flower and early fruit feeding by mirids may cause the fruit to drop. Wounds created by the mirids serve as entry points for decay organisms. The insects also lay eggs on opening buds, leaves, flowers, and small fruit (4).

\section{Scale (Chrysomphalus dictyospermi,} Chrysomphalus aonidum, Ceroplastes floridensis, Hemiberlesia lataniae, Protopulvinaria pyriformis)

Soft and armored scales are plant-feeding insects, often controlled by natural and released parasites, predators, and pathogens. In cases when the natural balance of predation has been disrupted, scale populations may increase to levels requiring chemical treatment. Since scale insects are relatively immobile, and at least one month is required for the scale-insect egg to reach the adult stage, an infestation builds up slowly (in comparison to mites or aphids) and may be hard to spot. It is important to verify that the scale insects attached to the plant are alive, as mummies accumulate on the plant over time.

Economic thresholds for scale have not been determined. Most effective control of scale insects is obtained when the scales are in nymphal stages; egg and adult stages are recalcitrant to insecticide applications (7).

\section{Avocado Tree Girdler (Heilipus squamosus)}

This weevil is one of the most potentially damaging pests of avocado. The adult weevil is about $1.2 \mathrm{~cm}$ in length, predominantly black in color with irregular white areas and spots on the wing covers. Eggs are deposited in the inner bark, near ground level. As the larvae feed, they burrow in the inner bark or in the wood of small trees. Reddish-brown frass extruding from burrowing holes is a sign of infestation. Young trees $2-4$ years old may be girdled so completely that the trees die. Adult weevils feed on avocado buds, twigs, and blossoms, as well as on young fruit after it has emerged (8).

\section{Redbanded thrips (Selenothrips rubrocinctus)}

The redbanded thrips is ubiquitous throughout Florida, but the pest is generally found in damaging numbers from Orlando to Key West. Female redbanded thrips are slightly greater than $1 \mathrm{~mm}$ in length with a dark-brown to black body underlain by red pigment, chiefly in the first three abdominal segments. The larvae is light yellow to orange with the first three and last segments of the abdomen bright red. The life cycle of this thrips is about three weeks in Florida, and several generations are possible each year. In addition to attacking avocado and mango, this thrips also attacks sweetgum trees. Redbanded thrips prefer young foliage. Infestations of redbanded thrips may cause leaf drop, at times totally denuding trees. The frass and associated sooty mold from thrips' feeding results in fruit that is out-of-grade (9).

\section{Red Imported Fire Ant (Solenopsis invicta)}

This ant is well known by most everyone living in the southern United States. Introduced near Mobile, AL, during World War II, this ant has spread throughout all the states that do not have freezing winters. Colonies of these ants can be either single-queen or multiple queen and can number up to a quarter million individuals. These ants take advantage of any food items available, including avocado fruit; fire ants are especially attracted to oily compounds. The ants may also protect aphid colonies from predators. The venom of the ant is highly irritating to mammalian skin, making picking avocadoes hazardous when ant colonies are actively foraging on trees (10). 


\section{Chemical Control}

For a schedule of yearly maintenance for Florida avocados, see EDIS Publication ENY-409, Insect

Management in Avocados, http://edis.ifas.ufl.edu/IG068 (4). During December through February, prune/survey for avocado tree girdler and lace bug and manage avocado red mites. From January through March, manage bloom-infesting insects. From May through July, prune wood from girdler attack and spray for scale, mealybug, or other major infestations. From August through September, manage thrips and fruit-scarring caterpillars.

Seventy percent of responding avocado growers surveyed reported insecticide use. Those survey respondents that provided estimates of insect damage indicated that without use of insecticide, from 10 - 90 percent of the avocado crop would be lost to insect damage ( $n=13$, mean of 60 percent) (11).

Insecticides and miticides registered for use in Florida on avocado in 2008 include the following: abamectin, azadirachtin, Bacillus thuringiensis, imidacloprid, malathion, methomyl, petroleum oils, permethrin, pyriproxyfen, insecticidal soap, pyrethrin +/- rotenone, metaldehyde (for slugs and snails), S-methoprene (for fire ants), and sulfur. Compounds for use only on non-bearing trees include the following: pymetrozine, bifenazate, fenpropathrin, hexythiazox, and bifenthrin. Additionally, fenoxycarb and hydramethylnon are registered for fire ants on non-bearing trees.

Permethrin is a pyrethroid insecticide that acts as a neurotoxicant. The compound is used to manage all avocado insects other than mites and armored-scale insects. The median price of permethrin is $\$ 56$ per pound of active ingredient. The approximate cost per application is $\$ 11$ per acre (12). The pre-harvest interval (PHI) for permethrin is 7 days, and the restricted-entry interval (REI) is 12 hours. No more than 1.2 pounds of active ingredient per acre per season may be applied.

Fifty percent of surveyed avocado growers in Florida apply permethrin either once (46 percent), twice (18 percent), three times (18 percent), four times ( 9 percent) or five times ( 9 percent) per season, for an average use of permethrin 2.2 times per season (11).

Fenoxycarb is a carbamate compound used as an insect-growth regulator. It causes death in the last pupal stage. The bait product is used to control ants (particularly the imported red fire ant). The price of fenoxycarb is $\$ 715$ per pound of active ingredient. The approximate cost per application is $\$ 14$ per acre (12). Twenty percent of surveyed avocado growers in Florida apply fenoxycarb to their non-bearing avocado groves once or twice per season (11).

Crop oils work by smothering immobile insects, such as scale, aphids, and mites. The oils are usually made up as solutions of 1.5 - 3 percent and applied thoroughly to each tree. Price varies greatly based on amount and formulation used. Twenty percent of surveyed avocado growers in Florida apply oil to their acreage once, twice, or three times per season (11).

Insecticidal soaps, like crop oils, work by asphyxiating non-winged insects. Again, prices vary widely, and solutions (e.g. 2 percent) are applied thoroughly to trees. Ten percent of surveyed avocado growers in Florida apply soaps to their trees four or six times per season (11).

Malathion is an organophosphorous compound. It causes death by interfering with proper nerve transmission. Malathion is used to control greenhouse whitefly, brown and lantania scale, and caterpillars. The median price of malathion is $\$ 5$ per pound of active ingredient. The approximate cost per application is \$26 per acre (12). The PHI for malathion is 7 days, and the REI is 12 hours. Ten percent of surveyed avocado growers in Florida apply malathion to their acreage once or twice per season (11).

Bacillus thuringiensis (B.t.) is a biopesticide used to manage lepidopteran larvae. The median price of B.t. is $\$ 140.16$ per pound of active ingredient. The approximate cost per application is $\$ 13.18$ per acre (12). B.t. may be applied up to the day of harvest (PHI 0 day), and the REI is 4 hours. Ten percent of surveyed avocado growers in Florida apply B.t. to their acreage once or twice per season (11). 


\section{Cultural Control}

Of all tropical-fruit-growing survey respondents, 44 percent reported keeping records of pest problems; 50 percent reported adjusting applications (timing or rate) to protect beneficial insects and mites, and 52 percent reported alternating pesticides to reduce resistance. Sixty-two percent reported selecting the pesticide that is least toxic to beneficial insects and mites, and 63 percent spot sprayed only infested plants or areas. Seventy percent reported selecting pesticides that are least toxic to the environment, making this the dominant form of cultural pest control (11).

\section{Biological Control}

Seven percent of the responding tropical-fruit growers reported release of predatory wasps for control of lepidopteran pests. Additionally, 30 percent reported the use of biological-derived pesticides like B.t. (11).

\section{Weed Management}

\section{Weed Pests}

Weeds can reduce avocado yields by competing primarily for water and nutrients. Although individual weed species may vary from region to region within the state, grasses, sedges, and pigweeds are the predominant weed species in Florida avocado groves (13).

\section{Chemical Control}

Herbicides labeled for use on bearing avocado include the following: simazine, glyphosate, carfentrazone, norflurazon, oxyfluorfen, paraquat, napropamide, and pelargonic acid. For non-bearing avocado trees, Fluazifop, trifluralin, sethoxydim, fluumioxazin, isoxaben, benefin, diquat, and oryzalin can be used. All of these herbicides are used to control weeds between trees. Ninety-five percent of avocado growers surveyed reported herbicide use (11).

Glyphosate is a phosphorylated amino acid herbicide used for total vegetation control. Glyphosate is applied as a directed spray, so avocado foliage is not injured. The median price of glyphosate is $\$ 11$ per pound of active ingredient. The approximate cost per application is $\$ 15$ per acre (12). The REI for glyphosate is 12 hours.

Ninety-five percent of surveyed avocado growers in Florida apply glyphosate either one (5 percent), two (5 percent), four (45 percent), five (20 percent), six (15 percent), seven (5 percent), or eight (5 percent) times per season. Average glyphosate use is 3.9 times per season (11).

Simazine is a triazine herbicide used in the management of certain grass and broadleaf weeds. Simazine is generally applied to the soil once a year. The median price of simazine is $\$ 4$ per pound of active ingredient. The approximate cost per application is $\$ 17$ per acre (12). The REI for simazine is 12 hours. Ten percent of avocado growers in Florida apply simazine to their acreage once per season (11).

Paraquat is a bipyridylium herbicide used for total vegetation control. Paraquat is applied in a directed manner to avoid injury to avocado foliage. The median price of paraquat is $\$ 12$ per pound of active ingredient. The approximate cost per application is \$11 per acre (12). The REI for paraquat is 12 hours when used as a post-directed spray. Ten percent of avocado growers in Florida apply paraquat once per season (11).

\section{Disease Management}

\section{Pathogens}

The principal diseases affecting avocado production in Florida include fungi, viroid, and algae. Depending on weather, Phytophthora root rot $(P$. cinnamomi) and seedling blight ( $P$. palmivora, $P$. parasitica) may be particular concerns. Scab (Sphaceloma perseae), spot (Pseudocercospora purpurea), anthracnose (Colletotrichum gloeosporioides), and wilt (Verticillium albo-atrum) are other fungal diseases that affect avocado production. Algal spot (Cephaleuros virescens) may become prevalent in late summer through late winter. A sun-blotch disease caused by a viroid may be latent for some time in the rootstock. Other diseases that intermittently affect avocado production are powdery mildew and stem-end rots $(14,15)$. 
Avocado Root Rot and Seedling Blight (caused by Phytophthora spp.)

Signs of avocado root rot include small leaf production and chlorosis on the leaves, which are prone to wilting. Leaf abscission is common with root rot, and new growth is absent. Roots become blackened and brittle, and the affected trees will often set a heavy crop of small fruit (14).

Irregular, reddish-brown necrotic areas appear on new leaves in cases of seedling blight. The areas expand rapidly along the larger veins. Lesions on young leaves are dark in color and cause the leaves to twist and curl. Stem lesions are elongate, sunken, and dark in color, as well (14).

\section{Scab (caused by Sphaceloma perseae)}

Scab is a pathogen of young leaves. Leaf resistance to scab increases greatly after one month of age. Colonization of scab is favored by cool, wet conditions. Signs of scab on leaves are small spots on the blade. The spots turn from dark purple/brown to gray, often leaving a star-shaped shot-hole. Leaves may become distorted and twisted if the infestation is heavy. Upon first inspection, lesions on petioles and twigs may be confused with scale insects.

Avocado fruit become resistant to scab at about half size. Scab is prominent on fruit of susceptible varieties, such as 'Lula'. Spots caused by scab on fruit are first oval, slightly raised, and purplish/brown. The spots form patches as they merge, and the centers of the spots may become sunken. A large portion of the fruit may become rough. Although the scab organism does not directly injure the fruit, the organism creates entry points, which fruit-rot organisms may colonize $(14,15)$.

Anthracnose (caused by Colletotrichum gloeosporioides)

Anthracnose infects the leaves and the fruit of the avocado plant. It is a weak pathogen, requiring entry portals, which may be created by Sphaceloma perseae or Cercospora purpurea. Once the fruit is infected, however, the anthracnose fungus rapidly degrades the quality of maturing fruit. Lesions become black and sunken, and a large portion of the fruit can also be overcome with the black decay. Pink spore masses may be observed as the fruit cracks $(14,15)$.

\section{Spot (caused by Pseudocercospora pupurea)}

Pseudocercospora infection first appears as small, angular brown or purple spots on the leaves, with yellow halos around many of the lesions. The spots are less than $3 \mathrm{~mm}$ across, but may overlap to form blotches of brown tissue. During rainy periods, when the fungus is most likely to flourish, grayish spore masses may be seen on the surface of the spots by using a hand lens. The fungus attacks fruit in a similar manner, except that fissures form in the spots on fruit. These fissures may lead to secondary infection (14).

\section{Algal Spot (caused by Cephaleuros virescens)}

This alga commences colonization late in the summer and progresses through the winter months. While visible symptoms are initially difficult to detect, green, yellow-green, or rust-colored leaf spots up to $5 \mathrm{~mm}$ in size eventually become raised and roughly circular. As spots on the upper leaf surface age, turning whitish-gray, the lesion becomes visible on the bottom leaf surface, turning dark green or brown. Heavy infestation may cause leaf drop. The alga eventually produces spores, which are rust colored and give rise to more algae if not controlled $(14,15)$.

\section{Sun Blotch}

The symptoms of this disease resemble sunburn. Leaves may exhibit white or pink mottling or variegation and distortion. Conspicuous, sometimes sunken white or yellow streaking may be apparent on the bark of young twigs and stems. Fruit will develop a red streak or lesion, which may be slightly sunken. Affected trees may be stunted or demonstrate willowy growth. The viroid that causes sun blotch may be transmitted by seed or by vegetative propagation (15). 


\section{Verticillium Wilt (caused by Verticillium albo-atrum)}

This soil-borne fungus is more prevalent in trees planted in historic areas of solanaceous crop production. The fungus invades water-conducting structures in the roots, causing a persistent wilt. Brown or gray streaks may be observed in the vascular tissue when the bark is peeled away. Leaves may die for lack of water, but remain attached for some time. Trees also may flush out with new shoots several months after collapse, apparently recovered from the infection (15).

\section{Chemical Control}

All responding avocado growers (100 percent) surveyed reported fungicide use. Survey respondents that provided damage estimates indicated that from 10 - 80 percent of the avocado crop would be lost to disease ( $n=8$, mean of 35 percent) without use of fungicides (11). Fungicides registered for use on avocado include the following: azoxystrobin, Bacillus pumilus, Bacillus subtilis, Trichoderma harzianum, mefenoxam, fosetyl aluminum, peroxide, potassium bicarbonate, copper, sulfur, and folpet.

Copper has long been used as a fungicide and can be applied in multiple forms (copper hydroxide, copper sulfate, etc.). Copper is used to manage anthracnose, scab, Cercospora spot, and algal spot $(14,15)$. The median price of copper hydroxide is $\$ 2$ per pound of active ingredient. The approximate cost per application is $\$ 19$ per acre (12). The $\mathrm{PHI}$ for copper hydroxide is 0 days. The REI is 24 hours. Based on survey results, 100 percent of avocado growers in Florida apply copper either once (5 percent), twice ( 5 percent), three times (14 percent), four times ( 9 percent), five times ( 24 percent), six times (24 percent) or seven or more times (19 percent) per season. Survey results indicate average seasonal use of copper is approximately 5.1 times (11).

\section{Sulfur}

As with copper, sulfur has long been used as a fungicide and can be applied in the form of copper sulfate or elemental sulfur. Sulfur is used to manage powdery mildew and anthracnose (as well as mites occasionally). The median price of sulfur is $\$ 1$ per pound of active ingredient. The approximate cost per application is $\$ 15$ per acre $(13,14)$. The PHI and REI for sulfur are 0 days and 24 hours, respectively. Based on survey results, 33 percent of avocado growers in Florida apply sulfur either once (43 percent), twice (14 percent), three times (29 percent), or six times (14 percent) per season. Survey results indicate an average use of sulfur is 2.4 times each growing season (11).

\section{Mefenoxam}

Mefenoxam is an acylalanine systemic fungicide used to manage Phytophthora root rot. The median price of mefenoxam is $\$ 157$ per pound of active ingredient. The approximate cost per application for mature trees is $\$ 500$ per acre (12). The PHI and REI for mefenoxam are 28 days and 48 hours, respectively. Mefenoxam is not to be used from November through February. Proper application of this product also includes restrictions on application number and total pounds used per year. These restrictions vary based on the formulation. Based on survey results, 10 percent of avocado growers in Florida apply mefenoxam to the entire grove once or twice each growing season, and 5 percent spot treat trees on an as-needed basis (11).

\section{Fosetyl-Aluminum}

Fosetyl-aluminum (fosetyl-Al) is an aluminum ester of alkyl phosphonate used in the management of Phytophthora root rot $(14,15)$. The median price of fosetyl-Al is $\$ 13$ per pound of active ingredient. The approximate cost per application is $\$ 53$ per acre (12). Restrictions include maximums of 4 applications per year and 16 pounds of active ingredient per acre per year. The PHI and REI for fosetyl-Al are both 12 hours. Based on survey results, 10 percent of avocado growers in Florida apply fosetyl-Al to their acreage once per season.

\section{Post-Harvest Control}

Careful handling during and after harvest, removal of infected avocados during grading, and adequate temperature maintenance can all aid in minimizing losses from post-harvest decays. In addition to the causative agent of anthracnose (Colletotrichum gloeosporioides), post-harvest 
disease organisms that can cause rotting (especially in immature fruit) include Diplodia natalensis, Dothiorella spp., and Lasiodiplodia spp. $(14,15)$.

\section{Nematode Management}

\section{Nematode Pests}

Plant-parasitic nematodes, which primarily attack plant roots, are microscopic roundworms found in soils. General signs of nematode damage include stunting, premature wilting, leaf yellowing, root malformation, and related symptoms characteristic of nutrient deficiencies. Stunting and poor stand development tend to occur in patches throughout the field as a result of the irregular distribution of nematodes within the soil. Species of nematodes reported to be associated with affected avocado trees include Radopholus similis, Pratylenchus brachyurus, and Rotylenchus reniformis (16).

\section{Chemical Control}

The only nematicides registered for use on avocado in Florida are harpin protein and azadirachtin. Harpin protein activates the systemic acquired resistance of a plant, using the endogenous immune system of the plant to ward off nematode attack. Azadirachtin is generally accepted as an insecticide, but little data is available with which to gauge the efficacy of this material against nematodes.

\section{Other Pests}

In addition to being susceptible to damage from insects, weeds, diseases, and nematodes, avocado fruit can also be damaged by slugs/snails and rodents. Two active ingredients are registered for slug/snail control in Florida avocado groves -- metaldehyde and a phosphoric acid/iron mixture. Five percent of the avocado growers surveyed employed a metaldehyde bait to control slugs/snails in their grove once per season (11). No rodenticides are actively registered for use in Florida avocado groves.

\section{Key Contacts}

Professor Jonathan Crane, of the Horticultural Science Department, Tropical Research and Education Center, Institute of Food and Agricultural
Sciences, University of Florida, is responsible for research and extension duties associated with tropical fruit. He can be reached at TREC,18905 SW 280th St., Homestead, FL 33031-3314, (305) 246-700, jhcr@ufl.edu.

Mark Mossler is a doctor of plant medicine in the U.F. Agronomy Department's Pesticide Information Office. Dr. Mossler provides information on pest management and pesticides to the public and to governmental agencies. He can be reached at UF/IFAS PIO, Box 110710, Gainesville, FL 32611, (352) 392 4721, plantdoc@ufl.edu.

\section{References}

1. Evans, E. and Nalampang, S. 2006. World, U.S. and Florida Avocado Situation and Outlook, EDIS Publication FE639, http://edis.ifas.ufl.edu/FE639. Food and Resource Economics Department, University of Florida/IFAS, Gainesville, FL.

2. Crane, J.H., Balerdi, C.F., and Maguire, I. 2007. Avocado Growing in the Florida Home Landscape, EDIS Publication CIR1034, http://edis.ifas.ufl.edu/MG213. Horticultural Sciences Department, University of Florida/IFAS, Gainesville, FL.

3. Economic Research Service, U.S. Dept. of Agriculture, in cooperation with the University of California. February 1995. Avocados: An Economic Assessment of the Feasibility of Providing Multiple-Peril Crop Insurance. Federal Crop Insurance Corporation.

4. Pena, J. and Johnson, F. 2003. Insect Management in Avocados, EDIS Publication ENY409, http://edis.ifas.ufl.edu/IG068. Department of Entomology and Nematology, University of Florida/IFAS, Gainesville, FL 32611.

5. Mead, F.W. and Pena, J. 2007. Avocado Lace Bug, EDIS Publication EENY039, http://edis.ifas.ufl.edu/IN166. Department of Entomology and Nematology, University of Florida/IFAS, Gainesville, FL, and Florida Department of Agriculture and Consumer Services, Tallahassee, FL. 
6. Pena, J.E., Sundhari, S., Hunsberger, A.,

Duncan, R., and Schaffer, B. 1998. Monitoring, Damage, Natural Enemies and Control of Avocado Lace Bug, Pseudacysta perseae (Hemiptera: Tingidae). Proc. Fla. State Hort. Soc. 111:330-334.

7. Browning, H.W. Childers, C.C., Stansly, P.A., Pena, J, and Rogers, M. 2007. 2008 Florida Citrus Pest Management Guide: Soft-bodied Insects Attacking Foliage and Fruit, EDIS Publication ENY604, http://edis.ifas.ufl.edu/CG004. Department of Entomology and Nematology, University of Florida/IFAS, Gainesville, FL 32611.

8. Wolfenbarger, D.O. 1948. Heilipus squamosus Lec., A New Enemy of the Avocado. Proc. Fla. State Hort. Soc. 61:260-264.

9. Denmark, H.A. and Wolfenbarger, D.O. 2007. Redbanded Thrips, EDIS Publication EENY099, http://edis.ifas.ufl.edu/IN256. Department of Entomology and Nematology, IFAS/University of Florida, Gainesville, FL, and Florida Department of Agriculture and Consumer Services, Tallahassee, FL.

10. Scheffrahn, R.H. 2005. Red Imported Fire Ant, EDIS Publication EENY195, http://edis.ifas.ufl.edu/IN352. Department of Entomology and Nematology, IFAS/University of Florida, Gainesville, FL, and Florida Department of Agriculture and Consumer Services, Tallahassee, FL.

11. UF/IFAS Pesticide Information Office. 2001. Tropical Fruit Management Survey. Agronomy Department, Institute of Food and Agricultural Sciences, University of Florida, Gainesville, FL.

12. Anon. Pricing.

13. Knapp, J.L. 1999. Citrus Commodity: A Biologic and Economic Assessment of Pesticide Usage. USDA National Agricultural Pesticide Impact Assessment Program Report No. 1-CA-99. U.S. Dept. of Agriculture Economic Research Service/National Agricultural Statistics Service.
14. Palmateer, A.J., Ploetz, R.C., and Harmon, P.F. 2006. 2006 Florida Plant Disease Management Guide: Avocado, EDIS Publication PP233, http://edis.ifas.ufl.edu/PG134. Plant Pathology Department, University of Florida/IFAS, Gainesville, FL.

15. Pernezny, K. and Marlatt, R.B. 2007. Diseases of Avocado in Florida, EDIS Publication PP21, http://edis.ifas.ufl.edu/VH047. Plant Pathology Department, University of Florida/IFAS, Gainesville, FL.

16. McSorley, R and Campbell, C.W. 1980. Relationship Between Nematode Density and Weed Density in Avocado Groves. Nematropica, Vol. 10, No. 2, 96-102. 